\title{
THE STRUGGLE OF FORTINBRAS AND HORATIO' IN ROMANIA: REMOVAL AND RE-COLLECTION OF THE COMMUNIST PAST IN ROMANIAN MUSEUMS
}

INTRODUCTION

M useums play an important role in society by constructing a place of rest for objects from the past. Through the content of their exhibits, museums present a specific view of the past, assist in understanding the present, and occasionally offer predictions for the future. They display forms of visual treasure to the public as a means to educate; and the physical presence of objects in museums are presented (and often taken) as evidence of objective truth. Most visitors give little thought to the way in which artifacts are placed, the symbolic nature of the location of the exhibits (and of the museum itself), or on how content was chosen at the exclusion of other material. Museums of history in particular hold a great deal of authority in the public eye and are perceived as institutions which protect the past, preserving the memory for future generations. However, museums often present or favor one memory over another. Curators are faced with the immense task of choosing what to present to the public and how to contribute or remain faithful to the collective memory of a society.

Museums, memorials and monuments are important spaces where societies develop new collective self-consciousness by dealing with and interpreting lemima PLOSCARIU received her Bachelor of Arts from Covenant College in Lookout Mountain, Georgia, USA and recently graduated with a Master of Letters in Central and Eastern European Studies from the University of St Andrews, Scotland. iploscariu@gmail.com

Gabriela Cristea and Simina Radu-Bucurenci, "Raising the Cross: Exorcising Romania's Communist Past in Museums, Memorials and Monuments", Oksana Sarkisova and Péter Apor (eds.), Past for the Eyes: East European Representations of Communism in Cinema and Museums after 1989 (Budapest, 2008), p. 301. In Hamlet Fortinbras wants to remove the dead bodies (the ruins) in the final scene but Horatio needs them in order to re-collect the story of the past. 
their own recent past. ${ }^{2}$ Museums ideally serve as places where communities "assert, contest, and negotiate social interests. " ${ }^{3}$ This was especially relevant to the peoples of the former Soviet bloc countries. With the collapse of communist regimes in eastern Europe at the end of the twentieth century, academics, politicians, and cultural leaders in the region faced the daunting but necessary task of helping their societies relate to a challenging recent past and prepare for an uncertain future.

In Romania the memory of the brutal regime of Nicolae Ceauşescu and the continued presence of former communists in government made difficult a popular consensus on how to present the communist past and how to overcome the regimes' legacy. Many memorials and monuments were built just after 1989 to commemorate the victims of the "communist tragedy." However, few exhibitions of the communist past are found in Romanian museums. The way in which museums treated the subject in post-communist Romania revealed the confusion and fear concerning the past that permeated society. It became evident that coming to terms with the past in Romania-the creation, management, and dissemination of representations of communist history and collective memory-focused on the victimization of Romanians. ${ }^{4}$ The response of victimization was a reoccurring theme across central and eastern Europe-such as in the Baltic countries, Poland, Hungary, and Ukraine. ${ }^{5}$ Post-communist Romanian museums also reveal the way in which the communist past was marginalized in the twenty years following the fall of Ceauşescu and how Romanian society, along with other former communist neighboring countries, are slowly coming to terms with the past.

Focusing on post-1989 museums, especially the Sighet Museum in Sighetul Marmației and the Romanian Peasant Museum in Bucharest, the article will examine three themes that appear in museum exhibitions of Romanian communist history: the marginalization of the communist past, the victimization of a nation, and the need by curators to "rescue memory." These approaches to the communist past have left a great deal out. Limited and biased portraits hindered a healthy coming to terms with the past initially intended by these institutions, which resulted in the continued dearth of nuance. However, some attempts have been made to bring in more voices and face the past on its own terms apart from the political motivation or desires for retribution of the present.

\section{TO THE MARGINS OF SPACE AND HISTORY}

Visitors to Hungary's National Museum of History first encountered the end of the era on entering the exhibition of the communist past. A large scale photo of Imre Nagy's reburial in June 1989 was the first object seen and as such the return to the "true path" of national history was anticipated before the "aberrant" communist years were even exa-

- *

2 Cristea and Radu-Bucurenci, "Raising the Cross", p. 276.

3 Ivan Karp, Museums and Communities: The Politics of Public Culture (Washington, DC: Smithsonian University Press, 1992), p. 6.

4 Cristian Tileagă, "The social organization of representations of history: The textual accomplishment of coming to terms with the past", British Journal of Social Psychology 48/2 (June 2009), p. 337.

5 "President champions museum of communist crimes", 17 August 2012, http://www.thenews.pl/1/9/ Artykul/109478,President-champions-museum-of-communist-crimes (accessed 10 October 2012); Beverly James, "Fencing in the Past: Budapest's Statue Park Museum", Media, Culture \& Society 21/3 (1999), pp. 291-311; James Mark, "What Remains? Anti-Communism, Forensic Archaeology, and the Retelling of National Past in Lithuania and Romania", Past and Present (2010), pp. 276- 300; Elena Ivanova, "Changes in Collective Memory: The Schematic Narrative Template of Victimhood in Kharkiv Museums", The Journal of Museum Education 28/1 Sociocultural Perspectives on Museums Part 1 (Winter 2003), pp. 17-22. 
mined. ${ }^{6}$ As in Hungary, the museum exhibitions on communism in Romania presented a powerful distinction between the normal course of national history and the digression that occurred with the installation of communism. The locations as well as content of the exhibitions that deal with the communist past conveyed the era as an aberration within Romania's national history. In an effort to reclaim parts of Romania's history that were suppressed under communism, museum curators stressed what was increasingly perceived by post-communist politicians and intellectuals as Romania's glorious interwar years. The pre-communist history was given pre-dominance in social discourse.

Duncan Light writes that society wished to ignore or forget the recent period of history; but the communist heritage was forced prematurely upon the people of Romania by curious foreigners and the tourist industry. ${ }^{7}$ A large percent of the population were in some way complicit with the communist regime's Securitate (secret police) and it is more likely many wanted to ignore their own contribution to the previous governments. ${ }^{8}$ The lack of money more than fear or the desire to forget was also influential in keeping Romania's most recent history behind closed doors. ${ }^{9}$ There did not seem to be an overwhelming desire for amnesia towards the past in society; however, the desire to minimize the power of the communist period on the present was evident. The National History Museum excluded the communist years and only showed Romanian history up to the 1920s. ${ }^{10}$ While at the Romanian Peasant Museum in Bucharest, the same building which was previously the Communist Party Museum, visitors now saw artful representations of Romanian rural history. ${ }^{11}$

The Peasant Museum's opening in 1990 as an ethnographic museum was an important means of protest against, as well as a symbol of victory over, what the building formerly housed: the propaganda and historical revisionism of the communist era. The rural Romanian tradition seemed an appropriate replacement to "exorcise the ghosts" of what curators saw as a fake museum. ${ }^{12}$ However, visitors had to go to the basement of the museum to see the exhibit. Irina Nicolau, a writer and ethnologist who worked alongside artist Horia Bernea in creating the museum, described the difficulty they faced in knowing, first of all, what to do with the artifacts of the previous museum and only secondly how to present communism in the new museum. Nicolau did not want to fall under the same accusation laid on the communist regimes of erasing the past; so she and the other curators gave much of the old museum's material away to the National Museum of History or to the State Archives and kept the rest in the basement. Despite not throwing away the communist era museum pieces, Nicolau, Bernea, loana Popescu and other museum team members viewed the objects as fake or referred to them as trash. ${ }^{13}$ With such a disdain for the objects that symbolized the recent past, an attempt at a fair por-

\section{$\cdots \cdots$}

6 James Mark, The Unfinished Revolution: Making Sense of the Communist Past in Central Eastern Europe (New Haven, 2010), pp. 89-90.

7 Duncan Light, "An Unwanted Past: Contemporary Tourism and the Heritage of Communism in Romania", International Journal of Heritage Studies 6/2 (2000), pp. 145-160.

8 Cătălin Augustin Stoica, "Once upon a Time There Was a Big Party: The Social Bases of the Romanian Communist Party (Part I)", East European Politics \& Societies 19/4 (Fall 2005), pp. 686-716.

9 "The Bad Couple", Economist 322/ 7741 (January 11, 1992), p. 86.

10 Light, "An Unwanted Past", pp.156-157. Light writes that it is unsurprising that the National History Museum shows some reluctance to approaching the subject of the Ceausescu years in the post-communist period considering the museum's important role in glorifying the Ceauşescus.

11 In 1996 the museum won European Museum of the Year. Cristea and Radu-Bucurenci, "Raising the Cross", p. 293.

12 Mark, The Unfinished Revolution, p. 87

13 Cristea and Radu-Bucurenci, "Raising the Cross", pp. 286-288. "Museum team and politicians dealt with the heritage of the old museum by declaring it a fake museum with fake objects." 
trayal or any portrayal at all of the communist era was difficult. Yet, in 1997 the Romanian Peasant Museum unveiled such an exhibit.

In the lowest depths of the building, Ciuma-O instalație politică (The Plague-a Political Installation) presented the process of collectivization on the peasants in Romania as "the moment when the imagined timeless existence of the Romanian peasant faced the violence of modern Romanian history." 14 However, the focus was on communism and visitors were not presented with a clear description of the plight of Romanian peasants. The communist kitsch and strong colors of the display achieved the desired aesthetic repulsion, hoping to evoke within visitors repugnance towards the communist past and everything these "fake" objects represented. Clippings of the communist party newspaper, Scânteia (The Spark), lined the walls, while one side was devoted to various (all very similar) portraits of former communist leader Gheorghe Gheorghiu-Dej. Small busts of Stalin and Lenin were arranged along the floor and what seemed like an altar piece with a portrait of Lenin brought up the end. ${ }^{15}$ There were no portraits of Ceauşescu. The exhibit was a strong contrast to the rest of the museum-representing a clear separation of this period from all others in Romania's history. In marginalizing the communist period the curators also hindered the voice of the peasants from being heard who suffered under collectivization.

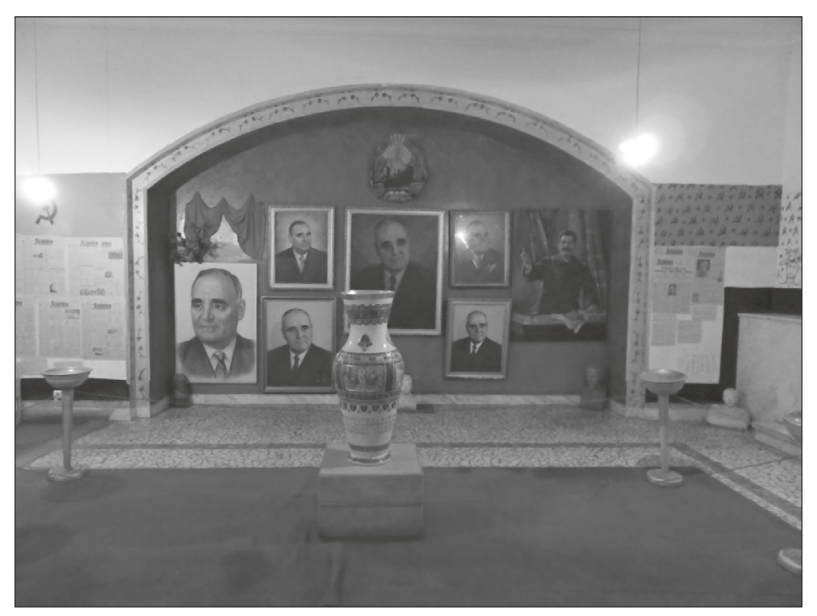

Figure 1: Museum of the Romanian Peasant ${ }^{16}$

Horia Bernea, the Peasant Museum's designer, said: “We couldn't exhibit the lies of the regime. We tried to exhibit its ugliness." 17 Bernea and the others succeeded in exhibiting the communist past in the most unattractive way; yet in doing so they robbed

\footnotetext{
14 Communism was shown to be an aberration not by removing it from history as in Riga's Museum of the Occupation of Latvia, but instead by representing the period as deviational within the larger history of the Romanian peasant, in Mark, The Unfinished Revolution, p. 90. Also in Cristea and Radu-Bucurenci, "Raising the Cross", pp. 293-295.

15 For a virtual tour of the Peasant Museum's Ciuma exhibit: http://www.tur.muzeultaranuluiroman.ro/.

16 More photos can be found at "Museum of the Romanian Peasant" http://flickrhivemind.net/flickr_hvmnd. cgi?method=GET\&page=2\&photo_number=32\&tag_mode=all\&search_type=Tags\&originput=museumoft heromanianpeasant\&sorting=Interestingness\&photo_type=250\&noform =t\&search_dodoma=Tags\&sort=| nterestingness\&textinput=museumoftheromanianpeasant (accessed 2 October 2012).

17 Cristea and Radu- Bucurenci, "Raising the Cross", p. 296. Horia Bernea and Irina Nicolau, "L'installation. Exposer des objets au Musée du Paysan Roumain", Martor: The Romanian Peasant Museum Anthropology Review 3 (1998), p. 226. The sound clip for the online virtual tour of the Ciuma exhibition also uses this phrase.
} 
visitors of anything but a one dimensional portrait of communism in Romania. The last thirty years of communism were not mentioned. The disjointed exhibit could not help visitors or the larger Romanian public to see the intricacies of the past forty-five years. They condensed the most recent traumatic period-crucial formative years for much of society-into one "ugly" room filled with "fake" things.

The treatment of the recent past by both museum curators and intellectuals in Romania could be seen as a means of, as Duncan Light puts it, concealing the material heritage that did not match with the new post-communist identity and democratic aspirations. ${ }^{18}$ Some intellectuals, such as the curators of the National History Museum, saw the recent past as a black hole to be forgotten so that the interwar period could be more easily reached-where real Romanian history and identity were thought to be found. ${ }^{19}$ The 1920s were held up as years of fruitful national awakening. The National Museum of History stopped its exhibits in this decade and the Sighet Memorial Museum focused on the prewar politicians Gheorghe Brătianu and Iuliu Maniu. The period was not a harmonious time (especially for minorities from the territories acquired through the Treaties of Versailles and Trianon); but it was a past that could be built upon which was completely different from the communist past. The Peasant Museum along with the outburst of historical revisionism occurring at the start of the 1990s, sought to directly join the pre-communist years to the post-communist present. ${ }^{20}$ Believing Romania's history was meant to unfold differently, curators attempted to correct what they believed was the grievous mistake of a forty year illegitimate rule by presenting the communist past as a deviation to the "natural teleology of national development." 21

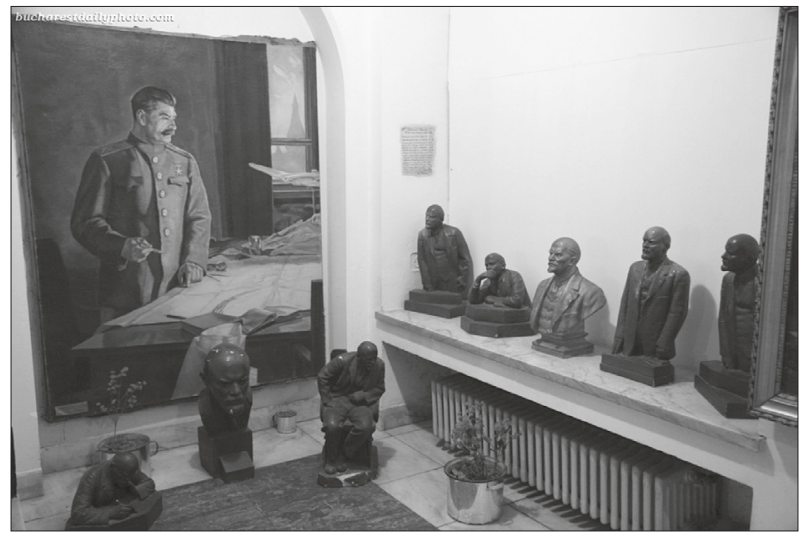

Figure 2: Romanian Peasant Museum²2

Communism as an aberration was also evident in the symbolic placement of exhibits and location of museums. The cramped basement exhibit was by the bathrooms in the Peasant Museum; as the curators believed the content was deserving of such an ignoble

18 Light, "An Unwanted Past", p. 158.

19 Simina Badica, "The black hole paradigm. Exhibiting Communism in Post-Communist Romania." History of Communism in Europe, ed. Institute for the Investigation of Communist Crimes and the Memory of the Romanian Exile (Bucharest: Zeta Books, 2010), pp. 83-101.

20 Light, "An Unwanted Past", p. 155. Writing Communist period out of the past proved more difficult for museums than perhaps for scholars who could produce work focused on a different part of the past.

21 Mark, The Unfinished Revolution, p. 87.

22 "Daily Photo-The Peasant Museum", www.bucharestdailyphoto.com/?s=museum\&amp;searchsubmit= (accessed 1 May 2012). 
space. ${ }^{23}$ The Sighet Museum, part of the Memorial for the Victims of Communism and of the Resistance, opened in 1997 in the town of Sighetul Marmației in the far northern county of Maramureş. This museum engaged directly with the communist past, yet the site chosen for it was the long abandoned Sighet Prison close to the border with the Ukraine. ${ }^{24}$ These marginalized spaces were a means of containing the power of the communist objects on display and their continued disputed influence in society. James Mark writes that marginal spaces provided a means to deaden and confirm the political irrelevance of the objects on display. ${ }^{25}$ However, by selecting authentic sites of terror curators used the history of the physical space to affect visitors.

Gabriela Cristea and Simina Radu-Bucurenci, both research assistants at the Romanian Peasant Museum, observe in their article that until 2004 the Sighet Museum held many empty cells. The signs reading "Exhibition under Construction" on the doors to these empty cells seemed to symbolize the continued construction of the memory of communism in Romania. ${ }^{26}$ After 2004 the empty cells were filled and a great deal of information was included on the destruction of pre-communist Romanian freedom and society. The role of space at the Sighet Museum provided unique symbolism of a former communist prison used to honor those who suffered while at the same time keeping the objects of the communist past confined within the prison walls and grounds. The museum invoked the horrors of the space as used under communism yet did not let the site tell the histories of Sighet's World War II Jewish and Hungarian victims. As such, it focused on the plight of the majority group at the expense of others who also suffered and reflected the continued marginalization of minorities in post-communist Romania.

Ana Blandiana, one of the museum's founders, drew on Holocaust museums and memorials in designing the Sighet Museum but did not provide information on how the Sighet Prison itself was linked to that period. The Museum of Genocide in Vilnius and the House of Terror in Budapest also focused on the communist era while marginalizing the history of the buildings under fascism. ${ }^{27}$ The Sighet Museum served as an important space of remembering but only of remembering certain aspects of the communist era; and as such it hindered a holistic approach to understanding the recent past. ${ }^{28}$ Such an approach also failed to give equal honor to victims of both totalitarian regimes who were from the ethnic minority populations.

Vladislav Todorov writes that the dilemma of ex-communist countries is whether to conquer the ruined space of the recent communist past by force or to ask for the Grand Ruin to be kept a ruin. ${ }^{29}$ Irina Nicolau, Horia Bernea, Blandiana, and others might have

-...

23 Cristea and Radu-Bucurenci, "Raising the Cross", p. 296

24 The Peasant Museum has a central location in Bucharest but it tries to give as little attention to the communist past as possible. The Sighet Museum by contrast is largely devoted to the communist era but far removed from any large cities or spaces of contemporary social, economic or political symbolism/significance.

25 Mark, The Unfinished Revolution, pp. 62-64. Mark gives the example of the city center location of Hungary's House of Terror because of its potential as an important political tool for the right wing Fidesz Party.

26 Cristea and Radu-Bucurenci, "Raising the Cross", p. 301. The authors remarked how the empty cells seemed more powerful than the ones filled with displays: "The blank spaces served as markers of forgetting and remembering...".

27 Mark, The Unfinished Revolution, pp. 67-69. The use of the Sighet Prison is controversial. It was barely in use after the 1950s and abandoned in 1970. It had to be renovated from ruins and the museum is not merely showing the spaces as they were originally. Similarly other memorial museums such as the House of Terror became part of the Ministry of Foreign Trade since 1956.

28 Sidonia Grama, "In Between Places of Remembrance and Realms of Memory: The 15-Years Commemoration of the Romanian Revolution in Timişoara", Philobiblon: Transylvanian Journal of Multidisciplinary Research In Humanities 10-11 (August 2005), p. 311. Grama emphasizes the political will needed for sites of memory and spaces of remembering to endure.

29 Vladislav Todorov, Red Square, Black Square: Organon for Revolutionary Imagination (Albany, NY: State University of New York, 1995), pp. 2-3. 
argued that the ruins must be conquered to either strip them of legitimacy and any influence on the present or to conquer in an attempt to redeem the ruins of space and memory of the pre-communist past. Unfortunately redemption of memory is mostly sought for the majority Romanian population; and politicians, academics, or other cultural figures who endorse such exclusive emancipation do not realize that through the exclusion of certain parts of the past they obstruct renewal and reconciliation for any of the victims.

The memorial museums attempt to provide a moral compensation for a revolution, according to James Mark, that does not seem completed-especially in Romania. The museums serve in the absence of justice for victims-they are cultural courtrooms that convict the former regime. ${ }^{30}$ These institutions attempt to come to terms with the past by categorizing communism as illegitimate and the recent past as a criminal deviation of history. ${ }^{31}$ The space of the Sighet Museum joins with that of the Peasant Museum to show communism in Romania as something foreign and to stress the victimization of the Romanian people.

VICTIMIZATION OF A NATION

Martyrdom of the Romanian nation under communism or "Soviet imperialism" and the non-responsibility of Romanians is a second reoccurring theme in the portrayal of the communist past in museums which influenced post-communist Romanian society. The individual Romanian citizen, James Mark claims, seemed to be defined by victimization alone and the entire post-communist nation was presented as victimized. ${ }^{32}$ The Association of Former Political Prisoners, who sponsored many of the monuments and memorials to victims of communism, labeled the years 1945 to 1989 as the period of "Soviet Devastation." 33 Novels and history books, such as those by Stelian Tănase, and influential politicians as Andrei Pleşu, contributed to the idea that aliens had brought the communist curse upon Romanians and that the Romanian people were not responsible. ${ }^{34}$ This was an attempt to externalize the guilt of so many citizens as outlined in C.A. Stoica's work on the wide-spread membership of Romanians in the communist party. ${ }^{35}$

The Sighet Museum in particular portrayed the Romanian people as victims of the imposed foreign system (with a few disloyal local people), amidst the glorified images of figures from the pre-communist past. The deaths at Sighet of prominent interwar and wartime politicians Gheorghe Brătianu, head of the right-wing National Liberal Party, and Iuliu Maniu, the leader of the interwar National Peasant Party, were used as powerful symbols of the wider suffering of the nation. As previously mentioned, this image of national victimhood was mostly identified with the dominant ethnic group. The entry hallway leading to the main prison was filled with photos of prisoners taken on their arrival at

30 Mark, The Unfinished Revolution, p. 64

31 Tileagă, "The social organization of representations of history", p. 351.

32 Mark, "What Remains?", p. 281.

33 Ibid.

34 Edward Kanterian, "Knowing Where the Graves Are: How Romania Has Begun to Deal with Its Communist Past", http://www.draculascastle.com/html/cgulag1.html (accessed 3 April 2012). Also in Cristea and RaduBucurenci, "Raising the Cross", pp. 280-284. The example given is Tănase's Clienții lu Tanti Varvara (Aunt Varvara's Clients) from 2004.

35 Cătălin Augustin Stoica, "Once upon a Time There Was a Big Party: The Social Bases of the Romanian Communist Party (Part II)", East European Politics \& Societies 20/3 (Summer 2006), pp. 447-482. 
Sighet Prison. Ana Blandiana, inspired by the Auschwitz memorial, wanted to honor the individuality of the victims by having their names inscribed on the walls of Sighet. ${ }^{36}$

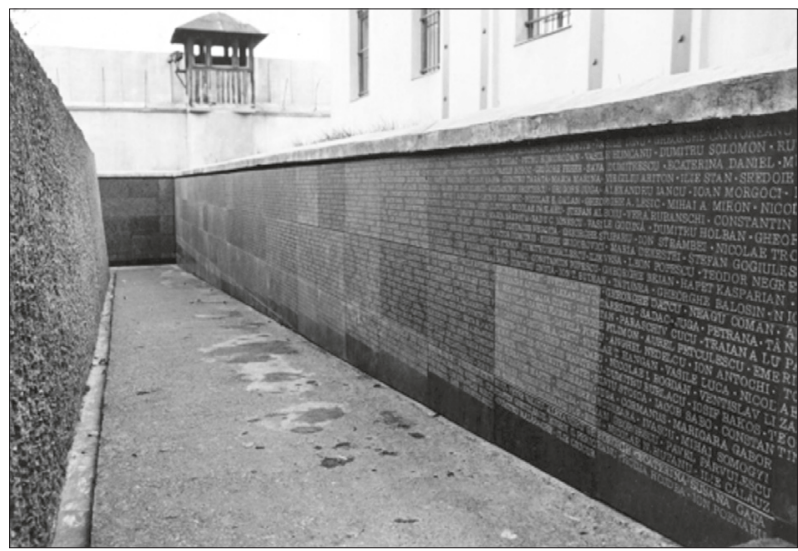

Figure 3: Space for Prayer and Recollection ${ }^{37}$

However, curators at Sighet and other museums downplayed Romania's fascist era. They feared that reviving the memory of fascist violence could undermine the power of the story of national suffering under communism or bring to mind the image of the Soviets as liberators. The fascist past was incorporated only in so far as to make the attack on communism more compelling. ${ }^{38}$ Some theories put forth were that many former fascists joined the communist ranks and continued committing atrocities; while right-wing politicians and admirers of World War II General Ion Antonescu stressed what they saw as the patriotism of the Iron Guard compared to the treachery of the communists. When excavations to find the remains of Brătianu and Maniu proved fruitless, their absence was presented as evidence of the inhumanity of the communist Securitate and of the continued power of ex-communists to hinder a reckoning with the past. The focus was on Romania's incomplete political transition which drew the public's attention away from the fact that the excavation and reconstruction of the communist prison was done at the exclusion of the prison's use during the fascist era. ${ }^{39}$ Cristea and Radu-Bucurenci provide an interesting analysis of the museum's exhibits as "a teleological understanding of the communist regime: from original sin, namely the forged elections, the subsequent crimes of repression and terror followed logically up to Ceauşescu's cult of power, ending in the emergence of resistance and victory of anti-communism." 40

The rise of anti-communist rhetoric among post-1989 Romanian politicians and intellectuals increasingly presented the communist past as a world divided into patriotic victims and traitorous collaborators. The use of museums and memorials to evoke the sense of "national martyrs" among the Romanian public encouraged a continuation of the anticommunist fight in the present. ${ }^{41}$ This approach gained popularity fifteen years into the

\section{......}

36 The official site of the Memorial of the Victims of Communism and of the Resistance: http://www.memorialsighet.ro/index.php?lang=en (accessed 27 April 2012).

$37 \mathrm{http}: / /$ www.memorialsighet.ro (accessed 6 October 2012).

38 Mark, The Unfinished Revolution, pp. 66-68, 115.

39 Mark, "What Remains?", p. 300.

40 Cristea and Radu-Bucurenci, "Raising the Cross", p. 301.

41 Mark, The Unfinished Revolution, pp. 216-217. 
new era as ex-communists like former president Ion Iliescu held less political power. In 2007, Romanian Minister of Culture Adrian Iorgulescu (at the opening of the temporary exhibit "The Golden Era: Between Propaganda and Reality" at Romania's National Museum of History) declared that Romania needed not a museum of communism but one honoring the fight of the victims against communism. ${ }^{42}$ The curators of the Sighet Museum saw this as its mission. The anti-communist discourse was more concerned with propagating the ideology of a continued struggle against an enemy that had survived and was still to be defeated, rather than encouraging reconciliation. ${ }^{43}$ Adam Michnik observed something similar occurring across the former Soviet Bloc:

"The old lie, the lie of communists settling scores with fascism, has been replaced by a new lie: the lie of anticommunists settling scores with communism . . . communism froze collective memory; the fall of communism, therefore, brought with it, along with a return to democracy, paratotalitarian formations, ghosts from another era ... The debate about communism has thus become, through blackmail and discrimination against political enemies, a tool in the struggle for political power." 44

This is seen in the unwillingness of post-communist era museums to present different types of memory and conflicting interpretations of the communist past. The majority of museum exhibitions on communism perpetuate one vision of a victimized past, where Romanians fought, suffered, and died for their country and their people in an attempt to overcome communism. Criticism of the Sighet Memorial Museum focused on its position as "a holy place of the Romanian Nation" where there is no room for debating memories. Although it is important to remember victims, the sole focus on a past of victims produced a one-sided history which lacked the realistic nuance of the past. ${ }^{45}$ Michal Kopeček writes of the need to distinguish between a legitimate reexamination of historical interpretations and attempts to rewrite history in a politically motivated way that denies crucial historical facts: "... different time-lines overlap in the social space and collective consciousness, resulting in a multiplicity of time, experience, and significance..." 46 These different time-lines were rejected in favor of one narrative of victimization which damaged social space and collective consciousness and hindered attempts to bring resolution.

SAVING A NATION AND ITS MEMORY

Rescuing, healing, redeeming, reconciling was declared the mission of museums by their curators. During the Iliescu, the Constantinescu presidential terms and beyond, the official policy seemed to be that of amnesia in regard to the recent past; and museum exhib-

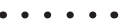

42 Cristea and Radu-Bucurenci, "Raising the Cross", pp. 276, 281. "In the anti-communist imagination the communist period is incorporated into the history of national suffering, the victims comparable to those of the First and Second World Wars."

43 Oana Popescu-Sandu, "'Let's All Freeze Up Until 2100 or So': Nostalgic Directions in Post-Communist Romania", Maria Todorova and Zsuzsa Gille (eds.), Post-communist Nostalgia (New York, 2010), p. 120. Sandu describes this as mythological blockage: obsession with the past political and national values that hinders progress.

44 Adam Michnik, "Mantra rather than discourse", Common Knowledge 8/3 (2002), pp. 516-525.

45 Cristea and Radu-Bucurenci, "Raising the Cross", p. 303.

46 Michal Kopeček (ed.), "Preface", Past in the Making: Historical Revisionism in Central Europe after 1989 (Budapest: CEU Press, 2008), p.vii. 
its were a means to combat this attempt to impose a collective amnesia. ${ }^{47}$ Ana Blandiana claimed the purpose of the Sighet Museum was to rescue the memory of Romanians, who, through "the greatest victory of communism," were stripped of their ability to remember who they were prior to the advent of communism. A resuscitation of the collective memory through exhibits showcasing the terror and victims of the past were meant to counteract that victory. ${ }^{48}$

At the Peasant Museum, Irina Nicolau and Horia Bernea sought to construct a museum of "healing and testimony." 49 Their first permanent exhibit, "The Cross," did not mention communism but it was Bernea's way of "exorcising communist ghosts." This was presented through a mix of Christian and traditional symbolism, by which communism would be exorcised from the museum and from society. ${ }^{50}$ Bonds between the living and the dead in Orthodox Christianity and peasant culture were used by museum curators to encourage the public to see the space as a place from which to invoke the memory of the victims (or in the case of Sighet's Cemetery of the Poor, the victims' remains) to help in the reconstruction of the new post-communist nation. ${ }^{51}$

The desire to "rescue memory" was part of a larger aspiration to build a new civil society. Facing up to the past and forming a new unifying national memory were important in achieving this new society. Much of the Romanian public believed this collective memory could only be achieved around the rejection of a criminal past. This was the case in Hungary, Lithuania, Estonia, and other former communist countries. The memory of communism was to be kept alive through its criminal condemnation and not by presenting it as a failed social and economic project. ${ }^{52}$ In 2006 the Presidential Commission for the Analysis of the Communist Dictatorship in Romania established a report by which communism could be officially condemned by President Traian Băsescu. ${ }^{53}$

The Commission's Final Report tried to provide an answer on how to process the communist past in public consciousness and steer the public use of history. However, coming to terms with the past as a process of overcoming its difficulties needed a serious working through of the past. ${ }^{54}$ This proved difficult, as the Vergangenheitsbewältigung that took place in Germany, with its elements of reassessment, coping, redress, and dealing with the past, were largely absent in eastern Europe. ${ }^{55}$ Evident in museum exhibitions, intellectuals and politicians sought a middle ground between that of collective amnesia and of nostalgia in coping with the past; and attempts were made to invoke the past in order to contrast it with and criticize the present. ${ }^{56}$ But the criticism was taken up by political parties against one another in the struggle to gain legitimacy.

\section{.......}

47 Vladimir Tismăneanu, "Democracy and Memory: Romania Confronts Its Communist Past", Annals of the American Academy of Political and Social Science 617 (May 2008), p. 168.

48 www.memorialsighet.ro (accessed 17 October 2012).

49 Badica, "The black hole paradigm", p. 90.

50 Cristea and Radu-Bucurenci, "Raising the Cross", pp. 281-290. Getting rid of the demons of Communism was a recurrent metaphor in narratives of post-communist museums and Romanian society. Eighty-two monuments were built between 1991 and 2004 and the majority were shaped in or marked with the form of a cross. All exceptions were in the Hungarian majority Szekler region.

51 Mark, The Unfinished Revolution, pp. 73-74.

$52 \mathrm{Ibid}, \mathrm{pp} .64-65,219$.

53 Vladimir Tismaneanu, Dorin Dobrincu, Cristian Vasile, Comisia Prezidentiala pentru Analiza Dictaturii Comuniste din Romania, Raport Final [Presidential Commission for the Analysis of the Communist Dictatorship in Romania, Final Report] (Bucharest: Humanitas, 2006). Traian Băsescu, Speech given with the Occasion of the Presentation of the Report by the Presidential Commission for the Analysis of the Communist Dictatorship in Romania, (18 December 2006), www. presidency.ro (accessed 17 April 2012).

54 Tileagă, "The social organization of representations of history", pp. 341-343.

55 Maria Todorova, "Introduction: From Utopia to Propaganda and Back", Maria Todorova and Zsuzsa Gille (eds), Post-communist Nostalgia (New York, 2010), pp. 3-4.

56 Ibid, p. 5. 
The motives of the Commission members were questioned, such as those of its president Vladimir Tismăneanu, who had strong family and personal ties to the communist regimes in Romania. ${ }^{57}$

President Băsescu clearly used the Report to gain legitimacy for his government and a moral upper hand on his political opponents. The Commission's Final Report did not present groundbreaking material to help "rescue memory", but contributed to the trend of broadening the term of victim to include the majority of Romanians. The use of the term "genocide" by Commission members to describe communist crimes spurred international response. ${ }^{58}$ The complicity of the Romanian public in the communist regimes and the acknowledgement of guilt were again over shadowed in the attempt made by Romanian politicians and intellectuals to align themselves with the democratic tradition and gain legitimacy. The Commission along with the museum exhibitions on communism often reflected the anti-communist approach of the era's victimization and deviation.

What curators and others hoped to achieve differed greatly from what was accomplished: the degree of healing brought to society and in developing collective memory of the recent past is debatable. Memories were often reinvented to fit with the new postcommunist rhetoric. ${ }^{59}$ The museum exhibitions came heroically to the rescue of selected memories while rejecting others. Rather than places for open discussion, many museums presented their answer as a pure and simple truth. ${ }^{60}$ Despite talk of confronting the past, many wished to simply sweep up and dispose of the ruins.

ROMANIAN SOCIETY

Romanian museums' treatment of the recent communist past revealed or encouraged perceptions in society of communism as an unnatural part of the nation's history and as a period of victimization of the Romanian people. This also contributed to the one-sided attempts to come to terms with the past by only giving a voice to some memories. These approaches were a legacy of the communist past (taking revenge on the recent past and building institutions that imposed a new national memory from above), which museum curators and the society at large were trying to overcome. ${ }^{61}$ Tensions rose after the Presidential Commission on the Analysis of the Communist Dictatorship suggested the construction of a National Museum of Communism. Vladimir Tismăneanu's advocacy for such a museum encountered great opposition and he was accused of communist nostalgia.

\section{......}

57 Tismăneanu is now a strong advocate for liberal democracy but his father, Leonte Tismăneanu worked in early post-war communist propaganda and was a professor of Marxist-Leninism in Bucharest. "Fişa de cadre a tatălui lui Vladimir Tismăneanu, Leonid Tisminețki. Tartorul ideologic al perioadei staliniste" ["Document of Rank for the father of Vladimir Tismăneanu, Leonid Tisminețki. Draconian ideological leader of the Stalinist period"] (28 July 2010), http://www.napocanews.ro/2010/07/fisa-de-cadre-a-tatalui-lui-vladimir-tismaneanuleonid-tisminetki-tartorul-ideologic-al-perioadei-staliniste.html (accessed 10 October 2012). V. Tismăneanu was himself formerly a proponent of neo-Marxism and involved in communist student propaganda until he left Romania in the 1980s.

58 Michael Shafir and Tom Gallagher among others voiced their objections to the scope of the Commission's "findings", the members chosen to be on the Commission, and the use of the Report for political gain. A volume in critique of the Report was published in 2008: Vasile Ernu, Costi Rogozanu, Ciprian Siulea şi Ovidiu Tichindeleanu (eds.), Iluzia anticomunismului. Lecturi critice ale Raportului Tismăneanu [The Illusion of Anticommunism. Critical Lectures of the Tismăneanu Report] (Chişinau, Moldovia: Cartier, 2008).

59 Oana Popescu-Sandu, "'Let's All Freeze Up Until 2100 or So': Nostalgic Directions in Post-Communist Romania", p.119.

60 Cristea and Radu-Bucurenci, "Raising the Cross", p. 277. The authors write that museums have the potential to be "Temples of the Nation presenting unique and single truth or as agoras of places for meeting, discussion and confrontation."

61 Mark, The Unfinished Revolution, p. 221. 
The proposed museum spurred a debate and forced people to engage in how memories of the communist past should be treated. A recent survey conducted by Romanian university students tackled and attempted to confront the Romanian public with the difficult issues discussed in this article. ${ }^{62}$ Questions in the survey included: whether every history museum should present the communist period and of what value are Communist era objects, if they hold any appeal today. They also asked to what extent should an exhibit on the Communist era include daily life, rural life, cultural activities, the economic situation, political evolutions, resistance towards the regime (both political dissidents and other forms of cultural dissent), and how closely it should resonate with the memories of visitors. The survey dealt with the political context and international influence, with the public's familiarity or ignorance, as well as with the role of exhibits to either encourage discussion or avoid controversy.

In recent years the public in Romania was more ready to engage with the communist past. Places like Dinel Staicu's Hotel-Museum of Communism in Scorniceşti was a ridiculous tribute to Ceauşescu used mainly for economic gain. ${ }^{63}$ Petitions were formed to turn other prisons, such as the Jilava prison, into museums in the same vein as that of the Sighet Memorial. ${ }^{64}$ In January 2012, students from two high schools in the southern city of Târgovişte started collecting artifacts to construct a museum of communism for the city. Gabriela Istrate, the director of one of the high schools involved said that by having students collect various objects from the communist era they were helping the Romanian youth "recuperate the past and become more informed" while hopefully helping the older generations not to forget. ${ }^{65}$ The students also conducted interviews, made videos, and produced animated short films as part of their project.

Sixty-nine year old Nea Sandu from Cluj also made a museum of communism in his home with a large collection of magazines, newspapers, trophies, portraits, and other objects from the era. ${ }^{66}$ However, the purpose of his personal exhibit was to present his nostalgia for life under Ceauşescu-an idealistic portrait of the past which the Târgovişte students hope to challenge through their project. There have been some attempts at virtual museums, which are interesting and even cleverly made, but which are incomplete and at points not very informative. ${ }^{67}$ This same deficiency among those coordinating collective memory at the national level hinders a better understanding of the recent past

62 Alexandra Zbuchea and Monica Bira (SNSPA), http://memoria.ro/ (Accessed 6 April 2012). The survey, in Romanian, is found at: https://docs.google.com/spreadsheet/viewform?formkey=dDVkbTQOWjIINWO0UzZ WWjJJTVRpU1E6MQ. The results have not yet been released.

63 "Hotel patru stele muzeul comunismului" ["Four Star communist museum hotel"], http://www.adevarul.ro/ actualitate/Hotel-patru-stele-muzeul-comunismului_0_29398276.html\#, and "Traseul lui Dinel Staicu de la museul comunismului la inchisoare via fotbal" ["Dinel Staicu's road from communist museum to jail by football"], http://www.romanialibera.ro/actualitate/justitie/traseul-lui-dinel-staicu-de-la-muzeul-comunismuluila-inchisoare-via-fotbal-223272.html, (accessed 27 April 2012).

64 "Fortul 13 Jilava - Muzeu al Comunismului?" ["Fort 13 Jilava- Communist Museum?"] (22 March 2010), http:// ro.altermedia.info/istorie-alternativa/fortul-13-jilava-muzeu-al-comunismului_19169.html (accessed 8 October 2012).

65 Izabela Oprean, "Elevii pun bazele unui muzeu al comunismului!" ["Students lay foundations for a museum on communism"], http://gazetadambovitei.net/educatie/308-altele/2350-elevii-pun-bazele-unui-muzeu-alcomunismului- (accessed 8 October 2012).

66 "Un clujean are acasă un muzeu al comunismului. Şi nu numai" ["A man in Cluj has a museum of communism at home"] (23 August 2012), http://www.provincianews.ro/un-clujean-are-acasa-un-muzeu-al-comunismului-si-nu-numai-video_15889.html (accessed 20 September 2012). The site offers an interesting video of Sandu's collection.

67 The virtual Global Museum on Communism has a section on Romania: http://romania.globalmuseumoncommunism.org/. The Institute for the Investigation of Communist Crimes and the Memory of the Romanian Exile sponsored an attempt at a clever website on the history of communism for younger people but it remains to be completed: http://www.istoriacomunismului.ro/\#/home. 
amidst the public. The Romanian National History Museum still does not have an exhibition of the country's communist past. ${ }^{68}$

The new Romanian cinema, current pop stars and other influential figures have presented the past anywhere from a thing of tragic humor to a monstrosity. ${ }^{69}$ When dealing with the idea of settling accounts, Slavoj Žižek writes that the gap between an actual biological death and a symbolic death can be filled either with "sublime beauty or fearsome monsters." 70 There is little to no attractiveness in the attempts to bring closure on the recent past within Romanian society; museums presented monsters rather than humans. However, the increase in society's farcical representations of what previously was viewed as a past of national tragedy reveals the need for museum curators to engage in the changing discourse of "re-signification."71

CONCLUSION

The Romanian Peasant Museum announced the coming of a new temporary exhibition on the period of collectivization for December 2012, which promised a more holistic approach to the plight of the peasants under communism. ${ }^{72}$ The curators called Romanian citizens to bring in any personal material artifacts (letters, photos, newspapers, tools, clothes, etc.) they would be able to contribute to the exhibition on collectivization. However, it is again a temporary exhibition. If a National Museum of Communism in Romania does become a reality the hope is that it will not follow suite with other representations of communism; that it would not become, as Gabriela Cristea and Simina Radu-Bucurenci predicted, "a place where demons are exorcised, visitors frightened to death, victims become martyrs and no third way is offered between victim and perpetrator...no questions, no dilemmas, no doubts, only answers." ${ }^{73}$ Museum curators should not seek to play the role of judges and construct their exhibits as courtrooms. Perhaps one of the most appropriate answers is to refrain from one-dimensional portraits when attempting to create an image of the past for those distanced from it temporally or ideologically. ${ }^{74}$

Communism as a national aberration, the victimization of the Romanian nation, and the need to rescue memory are loosing significance among younger generations. The symbols of Ceauşescu and the Securitate no longer captivate the public. The proposed National Museum of Communism faces intense opposition by those who feel the Sighet Memorial fulfills that position and on the other hand by a complacent population weary of unfruitful attempts to deal with the communist past. In the end, such a museum would be beneficial if it truly functioned as a place where questions of identity, heritage and memory are wrestled with and worked out, leaving room for debate and encouraging honest discussion. ${ }^{75}$

68 http://www.mnir.ro/ro/Default.aspx (accessed 8 October 2012).

69 Oana Popescu-Sandu, "'Let's All Freeze Up Until 2100 or So'”, pp. 114-121.

70 Slavoj Žižek, The Sublime Object of Ideology (London: Verso, 1989), p. 135

71 Diana Georgescu, "'Ceauşescu Hasn't Died': Irony as Countermemory in Post-Socialist Romania", Maria Todorova and Zsuzsa Gille (eds), Post-communist Nostalgia (New York, 2010), p. 159.

72 http://muzeultaranuluiroman.ro/acasa/distrugerea-taranimii-romane-ro.html (accessed 29 September 2012).

73 Cristea and Radu- Bucurenci, "Raising the Cross", p. 304.

74 Ferenc Laczó, "The Many Moralists and the Few Communists: Approaching Morality and Politics in PostCommunist Hungary", in Michal Kopeček (ed.), Past in the Making: Historical Revisionism in Central Europe after 1989 (Budapest: CEU Press, 2008), pp. 164-165. "It is not so interesting (if it is even possible) to attempt to classify someone as a good or evil person. It is much more fruitful to reflect on moral changes under Communism...public debate of people's moral performance under Communism has been lacking."

75 Ivan Karp, (ed.), Museums and Communities: The Politics of Public Culture (Washington, DC: Smithsonian University Press, 1992), p. 6. 


\title{
THE STRUGGLE OF FORTINBRAS AND HORATIO IN ROMANIA: REMOVAL AND RE-COLLECTION OF THE COMMUNIST PAST IN ROMANIAN MUSEUMS
}

\author{
Sum mary
}

Over twenty years after the dismantling of communist regimes began in Central and Eastern Europe, the governments and people in these former Soviet bloc countries are faced with varying and often opposing ways to approach and present the communist past. Focusing on post-1989 museums in Romania, especially the Sighet Museum in Sighetul Marmației and the Romanian Peasant Museum in Bucharest, the article will examine three themes that appear in museum exhibitions of Romanian communist history: the marginalization of the communist past, the victimization of a nation, and the need by curators to "rescue memory." These approaches to the communist past leave a great deal out. Limited and biased portraits hinder a healthy coming to terms with the past initially intended by these institutions in Romania and similar institutions across Central and Eastern Europe. However, some attempts have been made to bring in more voices and face the past on its own terms apart from the political motivation or desires for retribution, which often motivate the current interpretation of the past.

Keywords: Eastern Europe, Post-Communism, Romania, museums, memory

\section{WALKA FORTYNBRASA Z HORACYM W RUMUNII: LIKWIDACJA I PONOWNE PRZYPOMNIENIE KOMUNISTYCZNEJ PRZESZLOŚCI W RUMUŃSKICH MUZEACH}

\section{Streszczenie}

Po ponad 20 latach od chwili, gdy zaczęły się rozpadać komunistyczne reżimy w Europie ŚrodkowoWschodniej, rządy i społeczeństwa byłych krajów bloku sowieckiego doświadczają odmiennych, często przeciwstawnych podejść do komunistycznej przeszłości i sposobów jej przedstawiania. Skupiając swą uwagę na muzeach w Rumunii po roku 1989, zwłaszcza Miejscu Pamięci Ofiar Komunizmu i Ruchu Oporu w Sighetu Marmației (Syhot Marmaroski) oraz Muzeum Chłopstwa Rumuńskiego w Bukareszcie, autorka niniejszego artykułu analizuje trzy zagadnienia, które przewijają się w muzealnych ekspozycjach poświęconych dziejom Rumunii w czasach komunistycznych; są to: marginalizacja komunistycznej przeszłości, wiktymizacja narodu i potrzeba "ocalenia pamięci” przez kustoszy. Powyższe podejścia do komunistycznej przeszłości ignorują wiele kwestii. Niepełny i tendencyjny obraz opóźnia zatem dojście do ładu z przeszłością na zdroworozsądkowych zasadach, co w myśl początkowych założeń miało w Rumunii nastąpić dzięki muzeom, jak też dzięki podobnym placówkom w całej Europie Środkowo-Wschodniej. Jednakże podejmowane są wciąż nowe próby, aby dopuścić do głosu więcej różnych opinii i stawić czoło przeszłości niezależnie od motywacji politycznych bądź dążenia do zemsty, które często stoją za bieżącymi interpretacjami przeszłości.

Przekład z języka angielskiego

JACEK SERWAŃSKI 